\title{
EFEKTIFITAS SENAM OTAK (BRAIN GYM) TERHADAP FUNGSI KOGNITIF PADA LANSIA
}

\author{
The Effectiveness of Brain Gym on Cognitive Function in The Elderly \\ Nurli $^{1 凶}$, Idawati Ambo Hamzah ${ }^{2}$, Farmin Arfan $^{3}$ \\ ${ }^{1,2,3}$ Akademi Keperawatan YPPP Wonomulyo \\ E-mail: nurli190199@gmail.com
}

\begin{abstract}
ABSTRAK
Lanjut Usia (Lansia) adalah seseorang yang sudah mencapai usia 60 tahun keatas. Proses penuaan pada lansia ditandai adanya kemunduran biologis yang terlihat sebagai gejala-gejala kemunduran fisik, mental atau psikis.Berdasarkan data awal yang telah diperoleh di Kelurahan Sidodadipada tahun 2021 jumlah lansia yang berusia 60 tahun ke atas diperkirakan sebanyak 247 lansia (perempuan dan laki laki ).Beberapa tindakan yang dapat digunakan untuk mengatasi penurunan daya ingat antara lain dengan mengenal kemampuan-kemampuan yang masih dimiliki, terapi individu dengan melakukan terapi kognitif, terapi aktivitas kelompok dan senam otak. Penelitian ini adalah metode penelitian kuantitatif dengan paradigma positivitis. Desain penelitiannya adalah Preexperimental dengan one grup pretest postest. Hasil penelitian yang telah di lakukan menunjukkan bahwa senam otak memberikan perubahan efektif pada fungsi kognitif pada lansia. Sebelum dilakukan senam otak terdapat $4,45 \%$ penurunan fungsi kognitif dan kemudin Setelah dilakukan penelitian tentang senam otak membuat fungsi kognitif mningkat $2,5 \%$. Salah satu upaya pencegahan penurunan fungsi pada lansia adalah dengan melakukan senam otak, terjadi peningkatan fungsi kognitif pada lansia setelah di lakukan senam otak.
\end{abstract}

Kata Kunci: Efektifitas, Senam Otak, Fungsi Kognitif, Lansia

\begin{abstract}
Elderly (elderly) is someone who has reached the age of 60 years and over. The aging process in the elderly is marked by a biological setback that is seen as symptoms of physical, mental or psychological decline. Some actions that can be used to overcome memory decline include recognizing the abilities that are still possessed, individual therapy by doing cognitive therapy, group activity therapy and brain exercise. This research is a quantitative research method with a positive paradigm. The research design is pre-experimental with one group pretest posttest. The results of research that have been carried out show that brain exercise provides effective changes in cognitive function in the elderly. Before doing brain exercise, there was a $4.45 \%$ decline in cognitive function and then after doing research on brain exercise, cognitive function increased by $2.5 \%$. One of the efforts to prevent decline in function in the elderly is to do brain exercise, there is an increase in cognitive function in the elderly after brain exercise is done.
\end{abstract}

Keywords: Effectiveness, Brain Gym, Cognitive Function, Elderly. 


\section{PENDAHULUAN}

Seiring dengan kemampuan menurunnya fungsi tubuh, senam lansia akan membantu tubuh tetap bugar dan segar karena melatih tulang tetap kuat, mendorong jantung bekerja optimal, dan membantu menghilangkan radikal bebas yang berkeliaran di dalam tubuh. Hal ini sesuai dengan konsep senam lansia adalah olahraga ringan yang mudah dilakukan dan tidak memberatkan, yang dapat diterapkan. Penduduk lanjut usia mengalami peningkatan yang sangat signifikan. Proses penuaan penduduk tentunya berdampak pada berbagai aspekkehidupan, baik sosial, ekonomi, dan terutama kesehatan. Fungsi organ tubuh akan semakin menurun baik karena faktor alamiah maupun karena penyakit karena dengan semakin bertambahnya usia. Penurunan dalam hal fungsi kognitif yang salah satunya dapat dikarenakan oleh adanya gangguanotak dapat berdampak secara langsung pada kemampuan mengingat atau memori, kemampuan dalam berpikir, sikap dan bertingkah laku serta pada kemampuan memberikan penilaian disebut sebagai demensia, dimana factor yang menjadi penyebab kebanyakan dari demensia pada lanjut usia adalah penyakit Alzheimer. Penyakit tersebut dapat menyebabkan 70\% kasus kejadian demensia. Diperkirakan bahwa angka kejadian pada seluruh dunia kurang lebih 36 juta orang lanjut usia menderita demensia. Berdasarkan hasil studi terbaru akan terjadi peningkatan angka kejadian demensia yaitu 115 juta orang pada tahun 2050 (Ca et al., 2020).

Lanjut usia (Lansia) adalah seseorang yang sudah mencapai usia 60 tahun keatas. Proses penuaan pada lansia ditandai adanya kemunduran biologis yang terlihat sebagai gejala-gejala kemunduran fisik, mental atau psikis. Penduduk lanjut usia di Indonesia 2008 sebesar 21,2 juta jiwa, dengan usia harapan hidup 66,8 tahun. Tahun 2020 jumlah lanjut usia diperkirakan sebesar 28,8 juta jiwa dengan usia harapan hidup 71,1 tahun (Studi \& Keperawatan, 2010).

Berdasarkan data Badan Statistik Provinsi Sulawesi Barat jumlah lansia pada tahun 2007 sebanyak 6,54 \% dari seluruh lansia yang ada di Provinsi Sulawesi Barat yaitu 1,330,961. Berdasarkan data Kecamatan Wonomulyo, jumlah lansia (yang berusia 60 tahun ke atas) pada tahun 2019 yaitu 3842 lansia (K et al., 2021).

Berdasarkan data awal yang telah diperoleh di Kelurahan Sidodadipada tahun 2021 jumlah lansia yang berusia 60 tahun ke atas diperkirakan sebanyak 247 lansia (perempuan dan laki-laki ). Dan dari data yang kami peroleh banyak dari lansia kita di Kelurahan Sidodadi kurang melakukan olahraga khususnya seperti senam, dan banyak pula lansia yang kami temui mengalami penurunan daya ingat (pikun) secara berkesinambungan dengan waktu yang cukup lama. Terutama pada lansia perempuan yang kami temui kebanyakan darimereka tidak mudah mengingat tanggal atau bahkan hari.

Beberapa tindakan yang dapat digunakan untuk mengatasi penurunan daya ingat antara lain dengan mengenal kemampuan- kemampuan yang masih dimiliki, terapi individu dengan melakukan terapi kognitif, terapi aktivitas kelompok dan senam otak. Penelitian ini dilakukan terhadap lansia Kelurahan Sidodadi di khususkan terhadap lansia yang masih mampu duduk dan berjalan serta lansia yang seringkali mengalami kepikunan dalam waktu yang lama. 
Usia makin bertambah, maka otak juga mulai menua. Proses menua adalahproses alamiah yang akan dialami semua makhluk hidup. Fenomena menua juga terjadi pada sel-sel otak. Pada usia 70 tahun, bagian otak yang rusak bisa mencapai 5-10\% pertahun, hal ini berakibat pada proses berfikir yang menjadi lamban, sulit berkonsentrasi dan kemampuan daya ingat menurun(Bublikasi et al., 2015). Lansia bekerja namun kondisi fisik yang sudah tidak memungkinkan untuk bekerja (Fredy, 2021). Dalam sebuah penelitian yang telah dilakukan oleh Cancela, Suárez, Vasconcelos, Lima, \& Ayán, (2015) bahwa brain gym mampu meningkatkan kebugaran dan tingkat kognitif pada lansia (Erwanto et al., n.d.)

Penelitian tentang senam otak yang dilakukan oleh Sidarta (2003) memberikan kesimpulan bahwa senam otak pada orang dewasa sebanyak 2 kali seminggu selama 8 minggu ditemukan semua subyek mengalami kenaikan bermakna dalam tes kognitif termasuk didalamnya untuk mengukur fungsi memori jangka pendek,selanjutnya dalam penelitiannya menyatakan bahwa senam yang melibatkan kerja otak dapat memberikan pengaruh yang positif terhadap keseimbangannya. Bublikasi et al., 2015)

\section{METODE PENELITIAN}

Kegiatan ini dilakukan di kelurahan sidodadi Kecamatan Wonomulyo dengan kriteria inklusi yaitu lansia yang masih mampu melakukan gerakan, sebelum melakukan senam otak, terlebih dahulu kami melakukan pemeriksaan kesehatan seperti cek tekanan darah dan suhu lansia dan tetap dalam protokol kesehatan.

Kemudian populasi yang kami tetapkan yaitu KelurahanSidodadi dengan sampel 20 dari 247 data lansia yang didapatkan dari hasil olahan data. Lansia yang akan melakukan senamOtak duakali seminggu dengan kriteria inklusi adalah lansia yang berusia 60- 65 tahun keatas dan lansia yang mengikuti senam 2 kali seminggu, metode dalam pengumpulan data lansia yang kamigunakan yaitu metode kuantitatifdidapatkan dengan mengajukan Qusioner terhadap lansia danmengunjungilangsung lansia untukmelihat keadaan lansia kemudian dibuatkanlah data setelah melakukan pengecekan atau setelah dilakukan identifikasi terlebih dahulu, dari hasil qusioner maka dilakukanlah penetapan sampel. Penelitian ini adalah metode penelitian kuantitatif dengan paradigma positivitis.

Desain penelitiannya adalah Preexperimental dengan one grup pretest postest. Penelitian ini akan membandingkan rata- rata daya ingat jangka pendek lansia, sebelum diberikan senam otak dan setelah dilakukan senam otak. Kegiatan ini akan dilaksanakan pada tanggal 1 Mei 2021 dan akan berlangsung secara continue pada setiap jadwal pelaksanaan posyandu lansia yaitu setiap tanggal 20.Adapun lokasi pelaksanaan kegiatan ini yaitu pendopo wonomulyo yang bertempat disamping kantor kecamatan wonomulyo yang direncanakan akan diikuti sebanyak 22 lansia dan pada kegiatan selanjutnya akan dilaksanaan di halaman Masjid Kemerdekaan di kelurahan sidodadi. 


\section{HASIL DAN PEMBAHASAN}

Kegiatan penelitian ini di lakukan pada tanggal 21 april 2021 yang di laksanakan dari pukul 08 .00 S.d 10.00 WITA,bekerja sama dengan yayasan mandar indonesia. Dihadiri oleh Camat wonomulyo dan pak lurah sidodadi dan Direktur Akper YPPP Wonomulyo.kegiatan ini bertujuan untuk meningkatkan fungsi kognitif pada lansia kemudian di hadiri oleh lansia sebanyak 20 dari sarana yang di rencanakan.

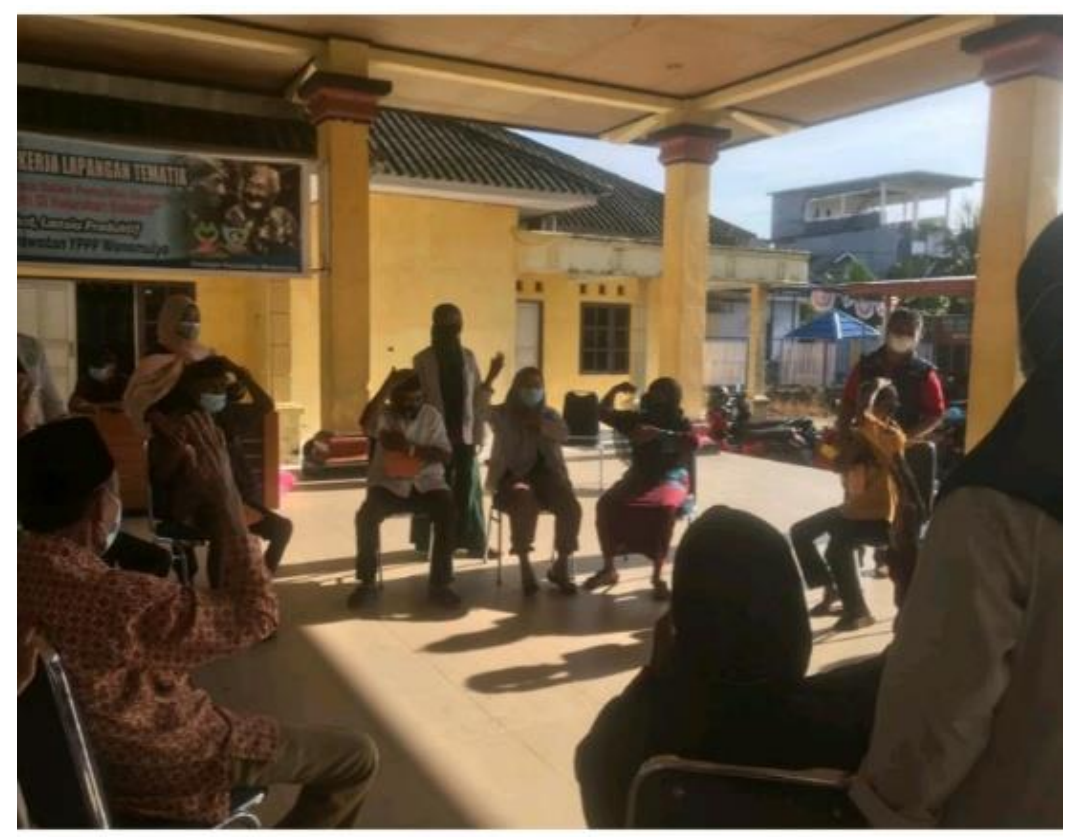

Tabel 1. Distribusi Usia dan Jenis Kelamin Responden

\begin{tabular}{lcc}
\hline \multicolumn{1}{c}{ Variabel } & Jumlah & Persentase (\%) \\
\hline Usia & & \\
60 tahun & 5 & 25 \\
$>65$ tahun & 9 & 45 \\
65 tahun & 6 & 30 \\
Jenis kelamin & & \\
Laki aki & 7 & 35 \\
Perempuan & 13 & 65 \\
\hline \multicolumn{1}{c}{ Jumlah } & 20 & 100 \\
\hline
\end{tabular}

Dari tabel di atas menunjukkan distribusi responden berdasarkan karasteristik lansia,manyoritas lansia dengan umur 60 tahun ke atas 9 orang (45\%)umur 65 tahun 6 orang $(30 \%)$ dan umur 60 tahun 5 orang $(25 \%)$ sedangkan jenis kelamin laki laki sebanyak 7 orang (35\%) dan perempuan sebanyak 13 orang $(65 \%)$. 
Tabel 2. Penilaian Kognitif Lansia sebelum dilakukan Senam Otak

\begin{tabular}{|c|c|c|c|c|}
\hline No & Skor & Kategori & Jumlah & Persentase \\
\hline 1 & $8-10$ & Berat & 4 & 20 \\
\hline 2 & $5-7$ & Sedang & 6 & 50 \\
\hline 3 & $3-4$ & Ringan & 10 & 30 \\
\hline \multirow[t]{2}{*}{4} & $1-2$ & Tidak mempunyai kerusakan & - & - \\
\hline & & Jumlah & 20 & 100 \\
\hline
\end{tabular}

Berdasarkan tabel 2 di atas didapatkan hasil berat berjumlah 4 orang atau $20 \%$ dan sedang 6 orang atau 50\% kemudian ringan 10 orang atau 30\% dan yg tidak mempunyai kerusakan intelektual adalah $1-2$ dan kerusakan hasil karasteristik peserta kegiatan penelitin masrakat usia peserta berada pada 60 s.d 65 tahun kemudian yang kami dapatkan intelektual ringan $3-4$ kemudian kerusakan intelektual sedang $5-7$ dan kerusakan intelektual berat $8-10$ selanjutnya di lakukan senam otak selama 15 menit.

Tabel 3. Senam Lansia Setelah Dilakukan Senam Otak

\begin{tabular}{|c|c|c|c|c|}
\hline No & Skor & Kategori & Jumlah & Persentase \\
\hline 1 & $8-10$ & Berat & - & - \\
\hline 2 & $5-7$ & Sedang & - & - \\
\hline 3 & $3-4$ & Ringan & 5 & 25 \\
\hline 4 & $1-2$ & Tidak mempunyai kerusakan & 15 & 75 \\
\hline & \multicolumn{2}{|r|}{ Jumlah } & 20 & 100 \\
\hline
\end{tabular}

Berdasarkan tabel 3 di atas didapatkan hasil bahwa setelah di lakukan kembali penilaiyan terjadi peningkatan post test dengan capaian nialai terendah adalah 3-4 ringan dan skor tertinggi 1-2 sangat baik.

Hasil yang di capai setelah di lakukan kembali pre test adalah 4,45 baik dan nilai post test rata rata adalah 2,5 sangat baik. Terjadi peningkatan nilai rata rata skor sebanyak $-1,957$ sehingga dapat di lihat bahwa lansia mengalami peningkatan kognitif dari ringan menjadi tidak ada kerusakan.

Senam otak merupakan serangkaian gerakan sederhana yang dapat menyeimbangkan setiap bagian-bagian otak atau latihan berbasis gerakan tubuh sederhana yang dapat dilakukan dimana saja dan kapan saja. Gerakan senam otak (brain gym) dibuat untuk merangsang otak kiri dan kanan, memperlancar aliran darah dan oksigen ke otak Pada prinsipnya dasar senam otak (brain gym)adalah ingin otak tetap bugar dan mencegah kepikunan.

Berdasarkan hasil penelitian yang telah di lakukan menunjukkan bahwa senam otak memberikan perubahan efektif pada fungsi kognitif pada lansia. Sebelum dilakukan senam otak terdapat $4,45 \%$ penurunan fungsi kognitif dan kemudin Setelah dilakukan penelitian tentang senam otak membuat fungsi kognitif mningkat $2,5 \%$. Salah satu upaya pencegahan penurunan fungsi pada lansia adalah dengan melakukan senam otak, subjek studi yang di ambil pada penelitian ini berdasarkan kriteria inklusi kemudian di lakukan intervensi selama 4 minggu 
dengan pemberian tindakan senam otak selama 15 menit dan di harapkan lansia dapat berpartisipasi karna kegiatan senam otak memiliki dampak positif terhadap peningkatan fungsi organ tubuh juga mempengruhi dalam fungsi imunitas dalam tubuh manusia jika dilakukan secara teratur dapat meningkatan daya kognitif pada lamsia dengan brain gym, karna menurut dari buku Erwanto et al., n.d. mengatakan bahwa brain gym mampu meningkatkan kebugaran dan tingkat kognitif pada lansia. Senam otak berguna untuk melatih otak. Latihan otak akan membuat otak bekerja atau aktif.

Senam otak berguna untuk melatih otak. latihan otak akan membuat otak bekerja atau aktif Menurut penelitian, otak seseorang yang aktif (suka berfikir) akan lebih sehat secara keseluruhan dari orang yang tidak atau jarang menggunakan otaknya .hal ini di sejalankan dengan pendapat (Aisyatu Al-Finatunni'mah 2020 ) yang mengatakan bahwa, senam otak dapat meningkatkan fungsi kognitif jika dilakukan selama 15 men

\section{KESIMPULAN}

Berdasarkan hasil penelitian terjadi peningkatan fungsi kognitif pada lansia yang di lakukan pada tanggal 21 April 2021 di dapatkan hasil terjadi peningkatan fungsi kognitif pada lansia setelah di lakukan senam otak. Karena Senam otak berguna untuk melatih.

\section{DAFTAR PUSTAKA}

Ca, R. W., Sari, D. K., \& Fatmawati, S. (2020). Penerapan Brain Gym Terhadap Tingkat Demensia Pada Lanjut Usia. 2(1), 1-6.

Erwanto, R., Aquino, T., Amigo, E., \& Yogyakarta, U. R. (n.d.). Efektifitas Art Therapy dan Brain Gym Terhadap Fungsi Kognitif Lansia. 1-12.

Fredy, A. (2021). Pemberdayaan Lanjut Usia dengan Aktivitas Rekreasi di Desa Sidorejo. Indonesian Journal of Community Dedication (IJCD), 3, 22-25.

K, F. A., Nur, H., \& Nengsih, W. (2021). Pemberdayaan Lanjut Usia dengan Aktivitas Rekreasi di Desa Sidorejo. 3, 22-25.

Santoso, B., Adriyani, Y., Kesehatan, P., Keperawatan, J., \& Palembang, K. (2013). Pengaruh terapi modalitas: terapi musik terhadap kualitas tidur lansia yang mengallami insomnia di panti tresna werdha teratai palembang. 1(November), 36-45.

Studi, P., \& Keperawatan, S. (2010). Pengaruh Terapi Senam Otak ( Brain Gym terhadap Daya Ingat Jangka Pendek Kapal Mengwi Badung. 5, 38-41.

Syapitri, H. (2014). Puskesmas Rantang Medan Program Studi Ners, Universitas Sari Mutiara IndonesiaEmail : mila_difa@yahoo.co.id Program Studi Ners, Universitas Sari Mutiara Indonesia_Email: heny_syahfitri86@yahoo.com. 44-56. 